\title{
RNF43 NP_060233.3:p.R127P
}

National Cancer Institute

\section{Source}

National Cancer Institute. RNF43 NP 060233.3:p.R127P. NCI Thesaurus. Code C146973.

A change in the amino acid residue at position 127 in the E3 ubiquitin-protein ligase RNF43 protein where arginine has been replaced by proline. 